\title{
DETERMINANTS OF NUTRITIONAL STATUS IN CHILDREN UNDER TWO YEARS OF AGE IN SRAGEN, CENTRAL JAVA
}

\author{
Sri Sayekti Heni Sunaryanti, Titik Anggraeni \\ Diploma Program in Nursing, School of Health Sciences \\ Mamba'ul 'Ulum, Surakarta
}

\begin{abstract}
Background: Malnutrition is one of the most important health and welfare problems among infants and young children in developing countries. This study aimed to examine the determinants of weight for age in children under 2 years of age in Sragen, Central Java.

Subjects and Method: This was a cross-sectional study conducted in Jetiskarangpung, Kalijambe, Sragen. A total of 107 children under 2 years of age were selected for this study by random sampling. The dependent variable was child growth as measured by weight for age score. The independent variables were exclusive breastfeeding, complementary feeding, immunization status, and child health care. The body weight was measured by a scale. The other data were collected by questionnaire. The data were analyzed by a multiple linear regression.

Results: Weight for age score increased with exclusive breastfeeding $(b=0.49 ; \mathrm{p}=$ 0.025), complementary feeding ( $b=0.26 ; p<0.001)$, immunization status $(b=0.65$; $\mathrm{p}=0.003)$, child health care $(\mathrm{b}=0.59 ; \mathrm{p}<0.001)$.

Conclusion: Weight for age score increases with exclusive breastfeeding, complementary feeding, immunization status, child health care.

Keywords: child growth, nutrition status, exclusive breastfeeding, complementary feeding, immunization status, child health care.

Correspondence:

Sri Sayekti Heni Sunaryanti, Titik Anggraeni. Diploma Program in Nursing, School of Health Sciences Mamba'ul 'Ulum, Surakarta, Central Java.

Email: ss.heni.s29@gmail.com.titikanggraeni_akpermus@yahoo.com.

Mobile: 085602025624, 085867292673
\end{abstract}

